\title{
GROWTH OF VERY LOW BIRTH WEIGHT PRETERM UNTIL 12 MONTHS OF CORRECTED AGE
}

\author{
Milene de Moraes Sedrez Rover ${ }^{1}$, Cláudia Silveira Viera ${ }^{1}$, \\ Beatriz Rosana Gonçalves de Oliveira Toso ${ }^{1}$, Sabrina Grassiolli ${ }^{1}$, Bruna Maria Bugs ${ }^{1}$
}

DOI: http://dx.doi.org/10.7322/jhgd.90228

\begin{abstract}
Introduction: facing the progressive increase in the survival of premature ta infants, a concern for health professionals would be related to the possible consequences arising from prematurity, among them the growth changes. Objectives: to describe the anthropometric variables of newborns Premature Very Low Birth Weight in the follow-up monitoring. Methods: observational, longitudinal and retrospective study, involving 71 children who left Neonatal Intensive Care Unit (NICU), with a weight lower than $1500 \mathrm{~g}$ who were treated between 2006 and 2013. They should have at least three outpatient visits within twelve months of corrected age after NCAU discharge, in the following periods: period I up to 3 months of corrected age; period II between 4-6 months of corrected age and period III between 7-12 months of corrected age. Results: the mean Gestational Age (GA) was 29.4 weeks, $51 \%$ male, birth weight $1073.2 \mathrm{~g}$, 70\% with appropriate GA. The hospitalization stay was 68.73 days. Weight $Z$ score at birth -0.95; at discharge -3.05; in period I -2.4; period II -1.8; period III -1.2 . Height at birth -1.21 , at discharge $-2.23 ;-2.5 ;-1.8$ and -1.1 for the periods I, II and III , respectively. Regarding the PT Z score at birth -0.71 ; at discharge -1.5 ; and monitoring -1.1 ; 0.8 and -0.5 respectively in the periods I, II and III. Conclusions: despite of the great Z score reduction in NICU, there was a progressive improvement during follow-up in the Z score in the three anthropometric variables.
\end{abstract}

Keywords: growth, infant, premature, extra uterine growth retardation, low birth weight.

\section{INTRODUCTION}

Nearly 15 million Premature (PT) are born each year in the world ${ }^{1}$, observing the context of the Neonatal Intensive Care Units (NICU) increased survival of PT with smaller gestational age (GA) ${ }^{2}$.

The increased PT survival, especially those with birth weight under $1,500 \mathrm{~g}$ - Very Low Weight Premature (VLWPT) is due to progress in the field of Perinatology in recent decades. However, even in the face of technological and human increment in neonatal care, the survivors may have short and long-term disability, complications, frequent rehospitalizations after discharge, neuropsychomotor development delays and growth changes ${ }^{1,3}$.

Facing these common PT complications, the monitoring of children's growth, translates into an essential tool for monitoring the child's health and the appropriate growth is determinant to have a satisfactory neurodevelopment in the future. The critical period for the development of the Central Nervous System comprises the last trimester of pregnancy and the first two years of life, this identifies a relationship with reserved neurological prognosis, especially in cases with insufficient or exaggerated growth of the Cephalic Perimeter $(\mathrm{CP})^{4}$. More recent studies have shown the importance of growth also in the first year of life, in order to avoid the development of chronic conditions such as hypertension, type 2 mellitus diabetes, cardiovascular disease and obesity ${ }^{5}$.

The PT feature growth pattern classified in four stages, variables as birth weight, gestational age and presented comorbidities. Initially, there are typical weight loss due to loss of extracellular fluid, reaching $15 \%$ of birth weight. The next one is the transition phase, clinical stabilization and caloric intake improvement, very slow growth, with priority to the increase of the CP and consequent brain growth. In the third stage the growth is accelerated,

1 Programa de Pós Graduação em Biociências e Saúde, UNIOESTE.

Corresponding author: Milene de Morais Sendrez Rover. E-mail: mmsrover@hotmail.com

Suggested citation: Rover MMS, Viera CS, Toso BRGO, Grassiolli S, Bugs BM. Growth of Very Low Birth Weight Preterm until 12 months of Corrected Age. Journal of Human Growth and Development. 25(3): 351-356. Doi: http://dx.doi.org/10.7322/jhgd.90228

Manuscript submitted Oct 22 2014, accepted for publication Dec 192014. 
growth recovery, rapid weight gain, stature and $\mathrm{CP}$, called catch-up, in which the values estimated in Intrauterine Growth Curves (IGC) or postnatal are exceeded. There are growth recovery when there is variation of the Z-score or standard deviation (SD) $e^{\prime \prime} 0.67$, between two consecutive $Z$ scores, i.e., rise of a channel in the curves of growth, more than a SD for more or with recovery above -2SD cornering. Occurring initially on the $\mathrm{CP}$ until the 12 months of life, followed by the long recovery and finally the weight. The newborn PT reaches the stage of equilibrium, with normal growth pattern, with speed similar to term newborn ${ }^{6,7}$.

Currently, the IGC is used as a reference standard in evaluating the growth in PT. However, the VLWPT hardly can hold that speed of post-natal growth, not only for weight loss, as the associated morbidities $^{8}$. Growth restriction may present in the neonatal period, with growth rates below those of intrauterine growth, leading to Extrauterin Growth Retardation (EGR). Constituting this in protein and energy deficit, in the first weeks of life that results in a lower growth than expected based on the curves of IGC (values below 10 percentile of IGC in accordance with estimated gestational age), affecting weight, stature and PC at the time of discharge, with 36 or 40 weeks of Corrected Gestational Age $\mathrm{A}^{9,10}$.

As the standard of IGC is still referenced in the neonatal period, it has been used during this period IGC curves. Recent study ${ }^{11}$ after systematic review and meta-analysis, seeking to harmonize the data with the curve of the World Health Organization (WHO)/(2006) with 50 weeks created new reference curve of IGC. After 40 weeks of corrected age using the WHO/2006 curves presented in the form of Zscore, with the corrected age to 3 years, since currently there is no specific curves, with welldefined criteria for the PT follow-up ${ }^{6,7}$.

In this context, with the survival rate of children born premature increase, specifically the VLWPT, most vulnerable group born in a period of intense growth, identifies the need to understand the dynamics of its growth, to define new guidelines and verify the occurrence of problems and growth deficits after the NICU ${ }^{12}$.

In this context, the study objective of this study is to describe anthropometric variables of preterm infants of very low birth weight in monitoring follow-up.

\section{METHODS}

Retrospective and longitudinal study in which were reviewed 305 medical records of patients treated in NICU between 2006 and 2013, of those 101 were Very Low Weight Premature (VLWPT). The inclusion criteria was as follows : newborns weighing under $1,500 \mathrm{~g}$, who remained hospitalized in NICU and after discharge took place at least three outpatient follow-up appointments, in the following periods: up to 3 months of corrected age (period I); between 4 to 6 months of corrected age (period II) and between 7 to 12 months of corrected age (period III). Were excluded from the medical records of patients with severe malformations or the ones who died during follow-up. The sample consisted of 71 of total 101 VLWPT records.

The data were collected by filling own instrument, using data from the records of the medical archive service, in which we reviewed birth and hospitalization medical records. Follow-up data were reviewed in ambulatory medical records. For classification of the Weight/IG relation was used the curve of Fenton and $\mathrm{Kim}^{11}$ with the help of Fenton growth chart calculations, online calculator, available at: http://www.ucalgary.ca/ fenton/.

To calculate the $Z$ score of anthropometric variables of the birth and the hospital was used to Survey mass calculator available in the same site described earlier. The Anthro program ${ }^{13}$ was employed to calculate the $Z$ score of anthropometric variables of the follow-up periods. When there were more consultations in the period was calculated $Z$ score of each query and then calculated the average for the period.

The information collected were entered in Microsoft Excel 2010, using the chronological age and corrected age in days, for later analysis descriptive statistics, mean and standard deviation. To compare the averages of the anthropometric measurements using single-factor ANOVA to XLStat 2014 program assistance. The study was approved by the Committee of Ethics in research with Human Beings Opinion number 385,407 .

\section{RESULTS}

Out of 71 newborns of the sample, 36 (51\%) were male, with gestational age (GA) average of $29.4 \pm 2.8$ weeks and average weight at birth of $1,073265.8 \pm .2 \mathrm{~g}$ of these patients, 50 (70\%) were suitable for the IG (AIG) and $20(28 \%)$ Small for the IG (PIG). During hospitalization (61\%) of 43 individuals used Parenteral Nutrition (PN), enteral diet full was achieved with $15.52 \pm 10.37$ days. The average length of stay was $68.73 \pm 27.2$ days. At the time of high 68 (95.6\%) were below 10 percentile of Fenton and $\mathrm{Kim}^{11}$. In the hospital 24 (34\%) were in exclusive breastfeeding, 34 (48\%) in suckling complemented by infant formula and $13(18 \%)$ with infant formula.

$Z$ scores averages for weight, height and Cephalic Perimeter (CP) are observed in table 1 and Figure 1. There are drop in Z score of three variables at the time of hospital discharge, mainly weight $(-3.05)$. There is an increase in the average of the $Z$ score until the end of the 12 months of follow-up, with period III values close to those of the birth.

Statistical difference was found between the evaluation periods of the $Z$ score for weight $\left(F_{4,280}=60.634 ; p=0.000\right), P C\left(F_{4,112}=8.7062 ;\right.$ $\mathrm{p}=0.000)$ and stature $\left(\mathrm{F}_{4,80}=6.8793\right.$; $p=0,00008)$. You can see in Figure 2, the values of birth weight (BW) were statistically equivalent to the weight in Period III ( $p>0.05)$. On the other hand the PN values were significantly higher when they are compared to other periods $(p<0.05)$. Compared 
Table 1 - Very Low Weight Prematures growth description in follow-up monitoring, 2006-2013

\begin{tabular}{|c|c|c|c|c|}
\hline & Mínimum & Media & SD & Maximum \\
\hline \multicolumn{5}{|l|}{ IN BIRTH } \\
\hline Weight (g) & 600,0 & 1073,2 & 265,8 & 1495,0 \\
\hline Heigh (cm) & 28,0 & 35,9 & 3,9 & 47,0 \\
\hline PT $(\mathrm{cm})$ & 22,0 & 26,1 & 2,5 & 32,0 \\
\hline CA (sem) & 24 & 29,4 & 2,8 & 36,0 \\
\hline Weight (escore Z) & $-4,1$ & $-0,95$ & 1,04 & 2,9 \\
\hline Heigh (escore Z) & $-6,1$ & $-1,21$ & 1,43 & 2,3 \\
\hline PT (escore Z) & $-4,2$ & $-0,71$ & 1,32 & 2,7 \\
\hline \multicolumn{5}{|c|}{ HOSPITALAR DISCHARGE } \\
\hline Weight (escore Z) & $-5,9$ & $-3,05$ & 1,21 & $-0,6$ \\
\hline Heigh (escore Z) & $-3,9$ & $-2,23$ & 1,14 & 1,5 \\
\hline PT (escore Z) & -5 & $-1,5$ & 1,45 & 2,7 \\
\hline \multicolumn{5}{|c|}{ PERIOD I (up to 3 CA months ) } \\
\hline Weight (escore Z) & $-6,2$ & $-2,4$ & 1,3 & 0,2 \\
\hline Heigh (escore Z) & $-7,3$ & $-2,5$ & 1,5 & 0,4 \\
\hline PT (escore Z) & $-4,2$ & $-1,1$ & 1,6 & 3,2 \\
\hline \multicolumn{5}{|c|}{ PERIOD II (4 - 6 CA months) } \\
\hline Weight (escore Z) & $-6,1$ & $-1,8$ & 1,3 & 2,5 \\
\hline Heigh(escore Z) & $-5,1$ & $-1,8$ & 1,7 & 7,0 \\
\hline PT (escore Z) & $-4,0$ & $-0,8$ & 1,4 & 2,9 \\
\hline \multicolumn{5}{|c|}{ PERIOD III (7 - 12 CA months) } \\
\hline Weight (escore Z) & $-4,7$ & $-1,2$ & 1,3 & 1,0 \\
\hline Heigth(escore Z) & $-4,3$ & $-1,1$ & 1,4 & 4,1 \\
\hline PT (escore Z) & $-4,0$ & $-0,5$ & 1,5 & 2,4 \\
\hline
\end{tabular}

Source: Author's data base

to the $\mathrm{CP}$, the analysis was performed in 29 children who presented all the information of the period of study for which the Z-score of the hospital was also considered statistically the lowest of the entire period $(p<0.05)$, the other medium-sized were not affected significantly in other periods evaluated ( $p>0.05)$. The stature was evaluated for the 21 children who presented all the information of the period of study. The $Z$ score average stature in the period I and on hospital discharge was considered statistically the lowest of the entire period ( $p<0.05$ ), and the other averages were not affected significantly in other periods evaluated ( $p>0.05)$.

The table 2 shows that the birth had 12 $(17 \%)$ Premature infants of Very low birth weight below -2 DP, however, at the time of 57 high ( $80 \%$ ) were below -2DP for weight. To 12 months of CA $73 \%$ of children followed in the clinic were with Zscore above -2 the weight, $75 \%$ compared to $86 \%$ and to the CP.

Table 2 - Z score frequency of $<-2$ with low growth pattern at birth, at discharge and three periods of outpatient follow-up, 2006-2013

\begin{tabular}{lcccccccccc} 
& \multicolumn{2}{c}{ Birth } & \multicolumn{2}{c}{ Discharge } & \multicolumn{2}{c}{ Period I } & \multicolumn{2}{c}{ Period II } & \multicolumn{2}{c}{ Period III } \\
Weight & $\mathbf{N}$ & \% & $\mathbf{N}$ & $\mathbf{\%}$ & $\mathbf{N}$ & $\mathbf{\%}$ & $\mathbf{N}$ & $\mathbf{\%}$ & $\mathbf{N}$ & \% \\
Heigth & 12 & 17 & 57 & 80 & 35 & 49 & 28 & 39 & 19 & 27 \\
PT & $20 / 68^{*}$ & 29 & $14 / 21^{*}$ & 67 & 43 & 61 & 30 & 42 & 18 & 25 \\
& $9 / 68^{*}$ & 13 & $7 / 29^{*}$ & 24 & 16 & 22 & 14 & 20 & 10 & 14
\end{tabular}

Source: Author's data base, 2014.

These data was not presentes in all the sample records.

\section{DISCUSSION}

This study demonstrated significant immediate postnatal Extrauterine Growth Retardation (EGR), while following progressive improvement in the $Z$ score of all the anthropometric variables.

The characterization of the sample in relation to weight, gestational age (GA), IG/weight ratio and length of stay identified that most of the results to the very low Weight premature infants (VLWPT) were similar to VLWPT in other national and international studies ${ }^{14,15}$.

The EGR, shown by the important fall on average of the $Z$ score of three anthropometric variables of birth until hospital discharge, presented averages of $Z$ score lower when compared to similar study ${ }^{16}$ carried out in four neonatal units of Rio de 
Janeiro, Brazil, where 570 premature were analyzed using the same assessment of the growth curve, and there were $39.1 \%$ high EGR, in relation to weight. In a study performed in India $^{17}$ and, Norway ${ }^{15}$ presented respectively, $63 \%$ and $57 \%$ of VLWPT below -2DP with 40 weeks of corrected age, also lower EGC indexes to those found in the present study.

The important EGC observed in this study may in part be explained by Comorbidities presented by VLWPT. such as the length of stay or being born Small for gestational age $(\mathrm{SGA})^{16}$. Additionally, our sample contained children prior to 2010, when there was no standardized routine service of Parenteral Nutrition (PN). Since the increment in relation to nutrition, with use of PN early; high rates of amino acids; use of early trophic diet with more aggressive increases contributes to improvement of growth during this period ${ }^{10}$. Thus, postnatal nutrition is fundamental and should receive special attention, with early enteral and parenteral feeding, stimulating growth and also the neuropsychomotor development. In the same way as the anthropometric assessment periodically which prevents future damage ${ }^{18}$, since it identifies changes early.

To 12 months of Corrected Age fewer children were with Z score below -2DP for weight, compared to the period I. Similar data has been found in a study carried out in São Paulo ${ }^{19}$, which was $31.5 \%$ index, considering only the 133 patients below 1500 g. In relation to the Cephalic Perimeter, 10 (14\%) patients were under-2DP, the highest rate compared to $6.7 \%$ obtained in the study cited earlier ${ }^{19}$. However, our results are similar to those found in a study ${ }^{20}$ carried out in the South of Brazil with 115 VLWPT accompanied the 12 months up to corrected age, which found $15 \%$.

In relation to the $\mathrm{Z}$-score for weight, height and $\mathrm{CP}$ during the 12-month follow-up, there is similarity in values found in follow-up study ${ }^{17}$ of growth conducted in India with 132 VLWPT, but with values to 12 months of at least 0.5 higher DP in this study. Although in ${ }^{20}$ a Brazilian study done in the South of the country, the $Z$ score during the following 6 and 12 months with $C A$, was higher in the variables of weight $(-0.89$ and -0.52$)$ and height $(-0.77$ and -0.38$)$ in relation to the values found in our study.

The Z-score of the hospital to the anthropometric variables was statistically the lowest of the entire period ( $p<0.05$ ), as a result, premature neonates in the first period suffered influences of this factor and difficulty to achieve the -2DP Z score. However, the 2 nd and 3 rd periods to gradual increase of $Z$ score have shown, as well as for stature. The CP showed gradual increase of $Z$ score from the hospital. The progressive improvement of the $Z$ score, shown in table 1 and Figure 1 , is observed in other studies ${ }^{17,20.21}$.

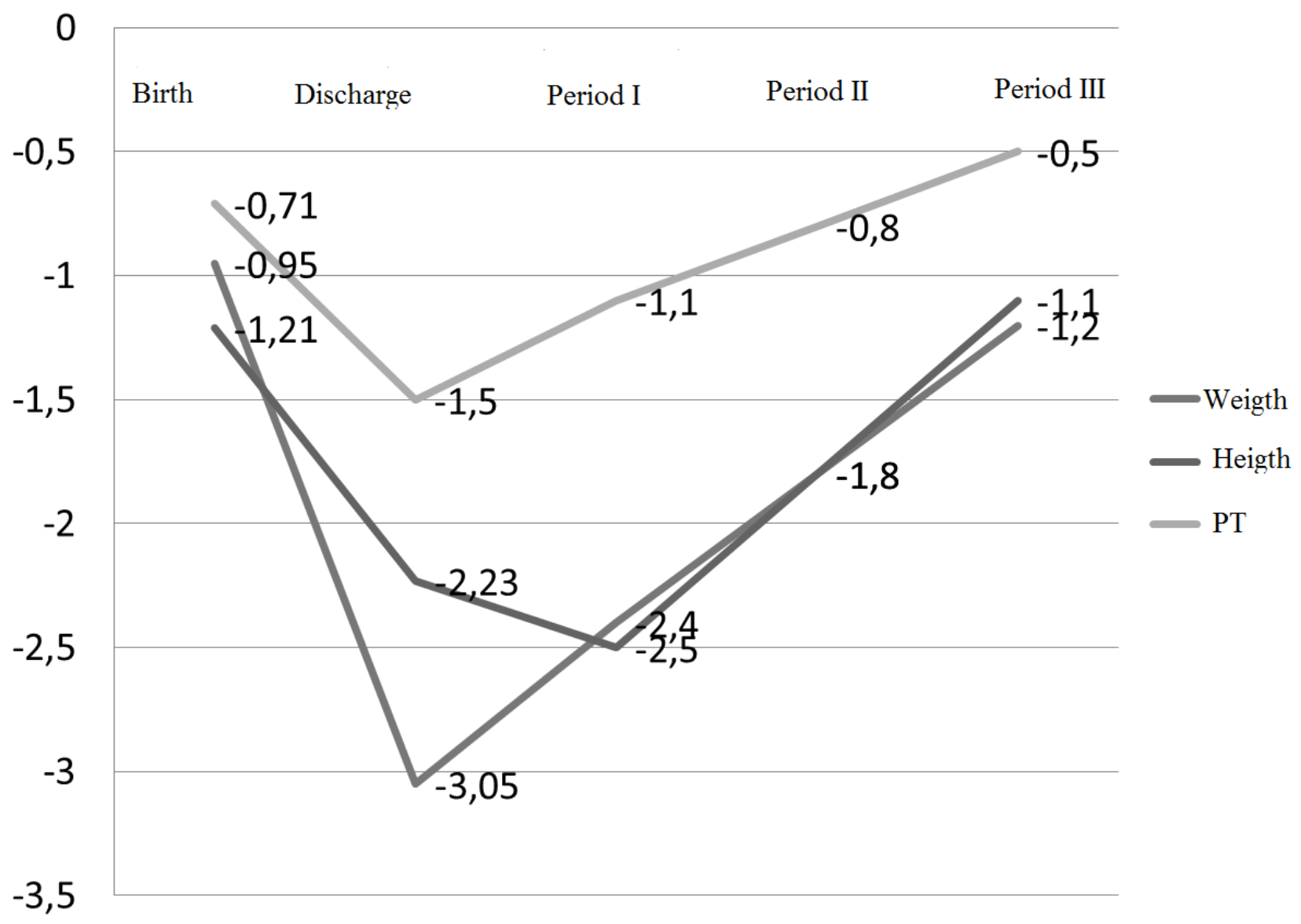

Figure 1: Z Score description of the variables Weight, Heigth and PT from birth till 12 months of corrected age of Very Low Weight Prematures in follow-up monitoring 
$F(4,280)=60,634, p=0,0000$

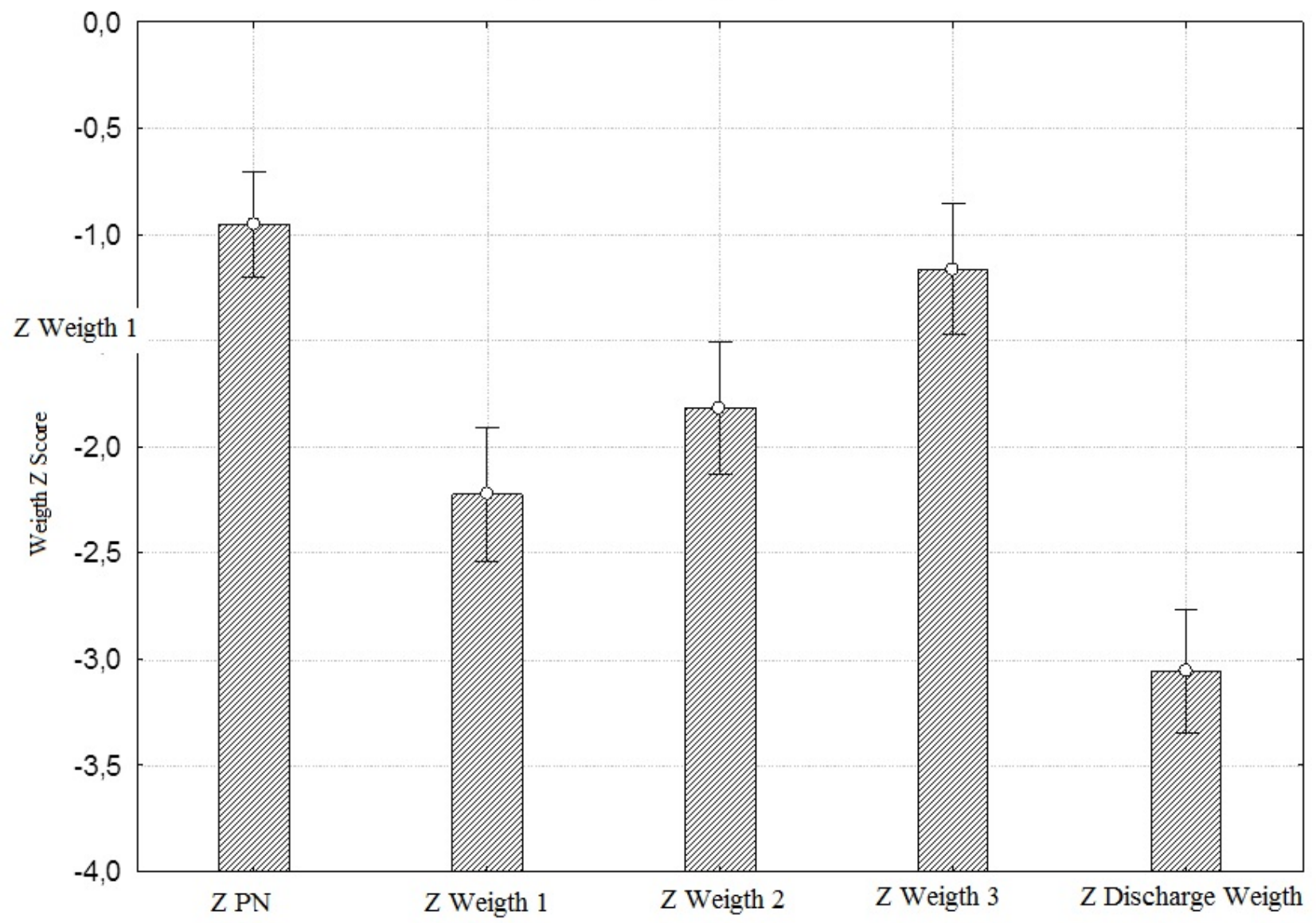

Figure 2: Z Score description of Weight on till 12 months of corrected age of Very Low Weight Prematures in follow-up monitoring

Differences in methodology, sample or benchmarks can explain the diversity of results in front of studies ${ }^{22}$, in which the authors identified higher $\mathbf{Z}$ score values to two years of age in preterm group, escorted the extremes 18 years of age. As well as higher percentage of extreme premature with growth failure ${ }^{23}(Z$ score $<-2)$ at 15 months of corrected age, in all anthropometric parameters evaluated, especially weight.

Thus, it is concluded that from the anthropometry of the newborn VLWPT it is possible to identify variations in their growth and the EGC

\section{REFERENCES}

1. World Health Organization (WHO). Born too Soon: the global action report on preterm birth. World Health Organization. Geneva: 2012; p.1-31.

2. Maranhão AGK, Vasconcelos AMN, Porto DL, França E. Mortalidade infantil no Brasil: tendências, componentes e causas de morte no período de 2000 a 2010. Brasília: Ministério da Saúde; 2012; p.165-82.

3. Silveira RC, Procianoy RS. Crescimento nos primeiros anos de vida de recém-nascidos de muito baixo peso. In: Procianoy RS, Leone CR, editores. Programa de Atualização em neonatologia. Artmed. Porto Alegre: Artmed; 2010; p.49-86. occurred during the period of hospitalization. The longitudinal follow-up of newborns VLWPT made it possible to evaluate the postnatal growth, demonstrating the influence of the EGC in the first few months at home (period I). In this sense, during the hospitalization in the NICU is need greatest attention to aspects that lead to this growth retardation to avoid this impact on the growth of PT after hospital discharge. It is concluded that the follow-up to the PT, the VLWPT, has high importance in order to determine what is the optimal growth for this group.

4. Cooke RWI, Foulder-Hughes L. Growth impairment in the very preterm and cognitive and motor performance at 7 years. Arch Dis Child. 2003;88(6):482-7. DOI: http:// dx.doi.org/10.1136/adc.88.6.482

5. Lapillonne A, Griffin IJ. Feeding preterm infants today for later metabolic and cardiovascular outcomes. J Pediatr. 2013;162(3 Suppl):S7-16. DOI: http://dx.doi.org/10.1016/j.jpeds. 2012.11.048

6. Rugolo LMSS. Crescimento e desenvolvimento a longo prazo do prematuro extremo. J Pediatr (Rio J). 2005; 81(Suppl 1): s101-10.

7. Cardoso-Demartini AA, Bagatin AC, Silva RPGVC, Boguszewski MCS. Crescimento de crianças nascidas prematuras. Arq Bras Endocrinol Metab. 2011;55(8): 534-40. DOI: 
http://dx.doi.org/10.1590/S000427302011000800006

8. Uhing MR, Das UG. Optimizing growth in the preterm infant. Clin Perinatol. 2009;36(1):16576. DOI: http://dx.doi.org/10.1016/j.clp. 2008.09.010

9. Shan HM, Cai W, Cao Y, Fang BH, Feng $Y$. Extrauterine growth retardation in premature infants in Shangai: a multicenter retrospective review. Eur J Pediatr. 2009; 168(9): 1055-9. DOI: http://dx.doi.org/10.1007/s00431-0080885-9

10. Ehrenkranz RA. Extrauterine growth restriction: is it preventable? J Pediatr (Rio J). 2014; 90(1): 1-3. DOI: http://dx.doi.org/10.1016/j.jped. 2013.10.003

11. Fenton TR, Kim JH. A systematic review and meta-analysis to revise the Fenton growth chart for preterm infants. BMC Pediatr. 2013;13:59. DOI: http://dx.doi.org/10.1186/1471-243113-59

12. Ministério da Saúde. Secretaria de Atenção à Saúde. Atenção à saúde do recém-nascido: guia para os profissionais de saúde. Cuidados gerais. Brasília: Ministério da Saúde; 2011.

13. World Health Organization (WHO). Softaware WHO anthro for personal computers manual. Software for assessing growth and development of the world's children. Geneva: WHO; 2011.

14. Lima PAT, Carvalho M, Costa ACC, Moreira MEL. Variables associated with extra uterine growth restriction in very low birth weight infants. ] Pediatr (Rio J). 2014;90(1):22-7. DOI: http:// dx.doi.org/10.1016/j.jped.2013.05.007

15. Westerberg $A C$, Henriksen $C$, Ellingvag $A$, Veierod MB, Júlíusson PB, Nakstad B, et al. First year growth among very low birth weigth infants. Acta Paediatr. 2010;99(4):556-62. DOI: http://dx.doi.org/10.1111/j.1651-2227. 2009.01667.x

16. Lima PAT, Carvalho M, Costa ACC, Moreira MEL. Author's reply: Z-score: Fenton 2013. Tem-year update. J Peditr (Rio J). 2014;90(4):427-8. DOI: http://dx.doi.org/10.1016/j.jped.2014. 04.004

17. Mukhopadhyay K, Mahajan R, Louis D, Narang A. Longitudinal growth of very low birth weight neonates during first year of life and risk factors for malnutrition in a developing country. Acta Paediatri 2013;102(3): 278-81. DOI: http:// dx.doi.org/10.1111/apa.12113

18. Oliveira AG, Siqueira PP, Abreu LC. Cuidados nutricionais no recém-nascidos de muito baixo peso. Rev Bras Crescimento Desenvolv Hum. 2008; 18(2): 148-54.

19. Goulart AL, Morais MB, Kopelman BI. Impacto dos fatores perinatais nos déficits de crescimento de prematuros. Rev Assoc Médica Bras. 2011;57(3): 272-9. DOI: http://dx.doi.org/ 10.1590/S0104-42302011000300008

20. Oliveira MG, Silveira RC, Procianoy RS. Growth of very low birth weigth infants at 12 months corrected age in southern Brazil. J Trop Pediatr. 2008; 54(1):36-42. DOI: http://dx.doi.org/ 10.1093/tropej/fmm 103

21. Pampanini V, Boiani A, De Marchis C, Giacomozzi C, Navas R, Agostino R, et al. Preterm infants with severe extrauterine growth retardation (EUGR) are at high risk of growth impairment during childhood. Eur J Pediatr. 2015;174(1):33-41. DOI: http://dx.doi.org/ 10.1007/s00431-014-2361-z

22. Roberts G, Cheong J, Opie G, Carse E, Davis N, Duff J, et al. Growth of extremely preterm survivors from birth to 18 years of age cmpared with term controls. Pediatrics 2013;131(2):e439. DOI: http://dx.doi.org/ 10.1542/peds.2012-1135

23. Claas MJ, Vries LS, Koopman C, Uniken Venema MMA, Eijsermans MJC, Bruinse HW, et al. Postnatal growth of preterm born children d"750 g at birth. Early Hum Dev. 2011; 87(7):495-507. DOI: http://dx.doi.org/ 10.1016/j.earlhumdev.2011.04.009

\section{Resumo}

Introdução: frente ao progressivo aumento da sobrevida de recém-nascidos prematuros, uma preocupação para os profissionais de saúde deve ser em relação às possíveis sequelas advindas da prematuridade, dentre elas as alterações de crescimento. Objetivos: descrever variáveis antropométricas de recém-nascidos Prematuros de Muito Baixo Peso em acompanhamento de followup. Método: estudo observacional, longitudinal e retrospectivo, em que participaram 71 crianças egressas da Unidade de Terapia Intensiva Neonatal, com peso menor de $1.500 \mathrm{~g}$, atendidas entre 2006 e 2013 e, que realizaram pelo menos três consultas ambulatoriais até doze meses de Idade Corrigida (IC), nos seguintes períodos: período I (até 3 meses de IC); período II (entre 4 a 6 meses de IC) e período III (entre 7 a 12 meses de IC). Resultados: a Idade Gestacional média foi de 29,4 semanas, sendo $51 \%$ do sexo masculino, com peso médio de nascimento de $1073,2 \mathrm{~g}$, sendo $70 \%$ adequados à IG. O tempo de internação médio foi de 68,73 dias. A média do escore $Z$ do peso ao nascimento de $-0,95$; no momento da alta hospitalar, de $-3,05$; no período I $-2,4$; período II $-1,8$; período III -1,2. Estatura: $-1,21$ ao nascimento, $-2,23$ na alta, $-2,5 ;-1,8$ e $-1,1$ nos períodos I, II e III, respectivamente. Em relação ao PC: escore $Z$ ao nascimento $-0,71$; alta $-1,5$; e seguimento 1,$1 ;-0,8$ e - -5 respectivamente nos períodos I, II e III. Conclusões: na descrição das variáveis antropométricas dos recém-nascidos prematuros durante a hospitalização até o terceiro período de seguimento observou-se retardo de crescimento extrauterino na internação e melhora progressiva nos índices de escore $Z$ das três variáveis antropométricas durante o seguimento ambulatorial.

Palavras-chave: crescimento, prematuro, retardo de crescimento extrauterino, muito baixo peso. 